\title{
Dermal Transforming Growth Factor- $\beta$ Responsiveness Mediates Wound Contraction and Epithelial Closure
}

\author{
Magaly Martinez-Ferrer, ${ }^{*}$ Ali-Reza Afshar-Sherif, ${ }^{*}$ \\ Consolate Uwamariya, ${ }^{*}$ Benoit de Crombrugghe, ${ }^{\dagger}$ \\ Jeffrey M. Davidson, ${ }^{\ddagger \S}$ and Neil A. Bhowmick ${ }^{\star}$ \\ From the Vanderbilt-Ingram Cancer Center and Department of \\ Urologic Surgery," and the Department of Pathology, ${ }^{\S}$ Vanderbilt \\ University School of Medicine, Nashville, Tennessee; the \\ Department of Molecular Genetics, ${ }^{\dagger}$ UT M. D. Anderson Cancer \\ Center, Houston, Texas; and the Department of Veterans Affairs \\ Medical Center, ${ }^{\ddagger}$ Nashville, Tennessee
}

Stromal-epithelial interactions are important during wound healing. Transforming growth factor- $\beta$ (TGF- $\beta$ ) signaling at the wound site has been implicated in re-epithelization, inflammatory infiltration, wound contraction, and extracellular matrix deposition and remodeling. Ultimately, TGF- $\beta$ is central to dermal scarring. Because scarless embryonic wounds are associated with the lack of dermal TGF- $\beta$ signaling, we studied the role of TGF- $\beta$ signaling specifically in dermal fibroblasts through the development of a novel, inducible, conditional, and fibroblastic TGF- $\beta$ type II receptor knockout (Tgfbr2dermalko) mouse model. Full thickness excisional wounds were studied in control and Tgfbr $2^{\text {dermalko }}$ back skin. The Tgfbr2 ${ }^{\text {dermalko }}$ wounds had accelerated re-epithelization and closure compared with controls, resurfacing within 4 days of healing. The loss of TGF- $\beta$ signaling in the dermis resulted in reduced collagen deposition and remodeling associated with a reduced extent of wound contraction and elevated macrophage infiltra-

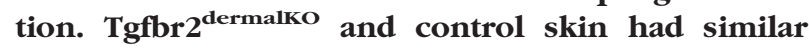
numbers of myofibroblastic cells, suggesting that myofibroblastic differentiation was not responsible for reduced wound contraction. However, several mediators of cell-matrix interaction were reduced in the Tgfbr $2^{\text {dermalko }}$ fibroblasts, including $\alpha 1, \alpha 2$, and $\beta 1$ integrins, and collagen gel contraction was diminished. There were associated deficiencies in actin cytoskeletal organization of vasodilatorstimulated phosphoprotein-containing lamellipo- dia. This study indicated that paracrine and autocrine TGF- $\beta$ dermal signaling mechanisms mediate macrophage recruitment, re-epithelization, and wound contraction. (Am J Pathol 2010, 176:98-107; DOI: 10.2353/ajpath.2010.090283)

Skin wound healing in adult humans after full-thickness injury results in scar tissue, which is prone to contracture, loss in elasticity, and altered tensile strength. The characteristics of a healed wound, unlike the original dermal tissue, include an extracellular matrix without the normal basket weave organization of collagen fibers that can be further exaggerated as a hypertrophic scar. In scars, there is a loss of normal tissue architecture and function due, at least in part, to altered cell-matrix interaction and the assembly of the actin cytoskeleton that occurs during wound repair. ${ }^{1,2}$ The actin cytoskeleton is important in processes that are fundamental to wound healing: migration; contraction; adhesion; and proliferation. ${ }^{3}$ The vasodilator-stimulated phosphoprotein (VASP) is associated with filamentous actin formation and likely plays a role in cell adhesion and motility. ${ }^{4}$ VASP may also be involved in the intracellular signaling pathways that regulate integrinextracellular matrix interactions.

Supported by Public Health Service grants DK069527 and CA108646 (to N.A.B.), AG06528 (to J.M.D.), the Department of Veteran Affairs, Vanderbilt-Ingram Cancer Center support grant CA68485, and Pathology Core of the Vanderbilt Skin Disease Research Center Core (AR41943). Laser confocal microscopy was performed through the use of the Vanderbilt University Medical Center Cell Imaging Shared Resource (supported by $\mathrm{NIH}$ grants CA68485, DK20593, DK58404, HD15052, DK59637, and EY08126). The content is solely the responsibility of the authors and does not necessarily represent the official views of the $\mathrm{NIH}$.

M.M.-F. and A.-R.A.-S. contributed equally to this work.

Accepted for publication September 2, 2009

Supplemental material for this article can be found on http://ajp. amjpathol.org

Address reprint requests to Neil A. Bhowmick, Ph.D., Department of Urologic Surgery, A1302 Medical Center North, 1161 21st Ave South, Nashville, TN 37232. E-mail: neil.bhowmick@vanderbilt.edu. 
The importance of stromal-epithelial interactions in development and wound healing is well established. These interactions likely involve autocrine and paracrine action of multiple growth factors, including members of the transforming growth factor- $\beta$ (TGF- $\beta$ ) family. TGF- $\beta 1, \beta 2$, and $\beta 3$ isoforms signal by binding to the TGF- $\beta$ receptors type I and type I at the cell surface. The ligand-receptor complex formed stimulates multiple parallel signal pathways in the cytoplasm. TGF- $\beta$ is a growth inhibitor for many cell types and stimulates extracellular matrix expression in mesenchymal cells. In the injured skin, macrophages, endothelium, fibroblasts, and epithelia are all sources of elevated TGF- $\beta$ expression. TGF- $\beta$ signaling at the wound site is thought to be important for extracellular matrix deposition and remodeling. The application of TGF- $\beta 1$ to wounds has been shown to accelerate wound healing. ${ }^{5}$ In apparent contradiction, a genetic knockout of the TGF- $\beta$ effector, Smad3, in mice exhibited accelerated skin and lens wound healing. ${ }^{6-8}$ However, the epithelial and stromal compartments can respond differentially to TGF- $\beta$ signaling, and the specific mechanism of TGF- $\beta$ action on any individual cell type within tissues is still not understood. Wounding of embryonic skin, in contrast to that in adults, is not associated with remodeling deficiencies associated with scarring. Interestingly, embryonic dermal fibroblasts lack expression of TGF- $\beta$ receptor type $11 .{ }^{9,10}$

In the present study, we specifically address the role of TGF- $\beta$ signaling in dermal fibroblasts by the development of a novel dermal fibroblast-inducible, conditional, TGF- $\beta$ type II receptor knockout (Tgfbr2 ${ }^{\text {dermalkO }}$ ) mouse model. The generation of Tgfbr2 ${ }^{\text {dermalkO }}$ mice provided an opportunity to test the role of TGF- $\beta$ in stromal cells in wound healing. The full-thickness skin excision wounds in Tgfbr2 ${ }^{\text {dermalkO }}$ mice had accelerated re-epithelization compared with control, impaired collagen organization associated with a lack of wound contraction, and reduced macrophage recruitment. The studies indicate that paracrine and autocrine TGF- $\beta$ dermal responsiveness mechanisms impact skin wound healing.

\section{Materials and Methods}

\section{Generation of Tgfbr2 ${ }^{\text {dermalkO Mice }}$}

To study the role of stromal TGF- $\beta$ signaling in dermal fibroblasts, we generated a conditional mesenchymal Tgfbr2 knockout mouse. We used the Cre expressing transgenic mouse model that is driven by the COL $1 \mathrm{~A} 2$ proximal promoter coupled to a mutated estrogen receptor that only binds tamoxifen. These COL1A2Cre-ER mice ${ }^{11,12}$ were crossed with Tgfbr2 floxE2/floxE2 mice $^{13}$ in the C57BL/6 background (Tgfbr2ColTKO). The resulting mouse was further crossed with the Rosa26 line ${ }^{14}$ to enable visualization of Cre-mediated recombination by staining for $\beta$-galactosidase activity. The mice were genotyped from ear DNA by PCR amplification of the Cre and Tgfbr2 genes. The studies described were performed with mice more than or equal to eight generations into the C57BL/6 background. Administration of
4-OH tamoxifen ( $10 \mathrm{mg} / \mathrm{ml}$ in sterile vegetable oil, $200 \mu \mathrm{l}$ ) activated Cre-mediated recombination at the site of interest (eg, skin). The mice were maintained in 12 hours dark/light cycles and were fed standard chow and water. All animal procedures were approved by the Vanderbilt Institutional Animal Care and Use Committee.

\section{Excisional Wounding Experiments}

Adult Tgfbr2 ${ }^{\text {ColTKO }}$ mice ( 8 to 15 weeks old) were anesthetized with isoflurane, shaved, and cleaned with Betadine (Purdue Products L.P., Stamford, CT). Excisional wounds were made 7 days after administration of $4-\mathrm{OH}$ tamoxifen or oil. In experiments for wound closure, two 4-mm full thickness excisional wounds were made with a biopsy punch. After wounding, a metal lock washer of 4-mm inner diameter was secured onto the wound site. Wounds were made on healthy mice in similar locations on either side of the back skin to ensure no site bias. Three to fourteen days after excisional wounding the mice were sacrificed, and the wound sites were removed and processed for histology and immunostaining.

\section{Histology and Immunohistochemistry}

Wound specimens, including a margin of nonwounded skin, were collected and fixed in $4 \%$ paraformaldehyde buffered with PBS (pH 7.2) and embedded in paraffin. Sections $(5 \mu \mathrm{m})$ were stained with H\&E for histological analysis. $\beta$-galactosidase staining was performed to visualized Cre-mediated recombination in the stroma. ${ }^{15}$ For immunohistochemical analysis, after antigen retrieval in 10 $\mathrm{mmol} / \mathrm{L}$ citrate buffer $(\mathrm{pH} 6.0)$, tissues were incubated with antibodies for phosphorylated-Smad 2 (1:1000; Cell Signaling, Boston, MA), keratin 5 (1:600 dilution; Covance Research Products, CA), Ki-67 (1:1000 dilution; Upstate USA Inc., Charlottesville, VA), F4/80 (1:50 dilution; Serotec, Raleigh, NC), von Willebrand factor VIII (1:400 dilution; Dako, Carpinteria, CA), and $\alpha$-smooth muscle actin (Dako) overnight in a humid chamber at $4^{\circ} \mathrm{C}$. All immunohistochemistry was detected by using Envision+ system peroxidase kit (Dako) according to the manufacturer's instructions. Masson's trichrome stain was used to evaluate collagen deposition. Picrosirius red staining ${ }^{16}$ was used to assess alignment and organization of collagen as well as a means of quantitating mature collagen fibers.

\section{Analysis of Re-Epithelization}

To measure the degree of re-epithelization, the wound section was viewed under $\times 100$ and $\times 400$ power. The width of the wound as well as the distance that the epithelium had traversed was measured. The percentage of re-epithelization was calculated based on the following formula: \% re-epithelization $=($ distance covered by the epithelium/width of wound bed) $\times 100 \%{ }^{17,18}$

\section{Isolation of Dermal Fibroblasts}

Skin tissue from newborn mice (24 to 48 hours) was isolated and rinsed in cold HBSS containing $100 \mathrm{U} / \mathrm{ml}$ 
Table 1. Primer Sets Used for Real Time RT-PCR Analysis

\begin{tabular}{lll}
\hline \multicolumn{1}{c}{ Primer } & Sense & \multicolumn{1}{c}{ Antisense } \\
\hline $\begin{array}{l}\text { Glyceraldehyde-3-phosphate } \\
\text { dehydrogenase }\end{array}$ & $5^{\prime}$-CGTGCCGCCTGGAGAAAC-3' & 5' $^{\prime}$-AGTGGGAGTTGCTGTTGAAGTC-3' \\
$\alpha 1$ integrin & & \\
$\alpha 2$ integrin & $5^{\prime}$-TCTCTCGCCAGCTTTGGAAGTCAT-3' & $5^{\prime}$-TACTGGAGTTGGGCAGCATGGTAA-3' \\
$\beta 1$ integrin & $5^{\prime}$-TGCCGGTCGATGGAACAGAAGTAA-3' & $5^{\prime}$-TGAAGGCTTGGAAATTGATGGCCG-3' \\
Collagen I $\alpha 1$ & $5^{\prime}$-TTCAGACTTCCGCATTGGCTTTGG-3' & $5^{\prime}$-TGGGCTGGTGCAGTTTGTTCAC-3' \\
Collagen I $\alpha 2$ & $5^{\prime}$-TTCTCCTGGCAAAGACGGACTCAA-3' & $5^{\prime}$-AGGAAGCTGAAGTCATAACCGCCA-3' \\
Collagen III & $5^{\prime}$-AGGCGTGAAAGGACACAGTGGTAT-3' & $5^{\prime}$-TCCTGCTTGACCTGGAGTTCCATT-3' \\
\hline
\end{tabular}

penicillin, $0.01 \mathrm{mg} / \mathrm{ml}$ streptomycin, and $50 \mu \mathrm{g} / \mathrm{ml}$ gentamicin. To trypsinize the skin, tissue was incubated in $0.2 \%$ trypsin in HBSS containing penicillin-streptomycin and gentamicin at $4^{\circ} \mathrm{C}$. After overnight incubation, the dermis was isolated and digested by using $0.2 \%$ collagenase type I in Dulbecco's modified Eagle's medium (DMEM) containing $10 \%$ fetal bovine serum (FBS) at $37^{\circ} \mathrm{C}$ for 1 hour. Digested skin was filtered by using a $70-\mu \mathrm{m}$ cell strainer and centrifuged at $1000 \mathrm{~g}$ for 5 minutes. The pellet was resuspended in stromal media (DMEM F12, $10 \%$ FBS, $50 \mu \mathrm{g} / \mathrm{ml}$ gentamicin, $10 \%$ Nu serum, $100 \mathrm{U} / \mathrm{ml}$ penicillin, $0.01 \mathrm{mg} / \mathrm{ml}$ streptomycin, $0.25 \mu \mathrm{g} / \mathrm{ml}$ Fungizone, and $0.1 \%$ insulin), and incubated at $37^{\circ} \mathrm{C}$. After cells were confluent they were split and used for experiments.

\section{Western Blotting}

Dermal fibroblasts were sonicated in $25 \mathrm{mmol} / \mathrm{L}$ HEPES buffer, pH 7.5 (containing $300 \mathrm{mmol} / \mathrm{L} \mathrm{NaCl}, 20 \mathrm{mmol} / \mathrm{L}$ $\beta$-glycerol phosphate, $2 \mathrm{mmol} / \mathrm{L}$ sodium pyrophosphate, $1 \mathrm{mmol} / \mathrm{L}$ EDTA, $0.2 \mathrm{mmol} / \mathrm{L}$ EGTA, 0.1\% SDS, 1\% Triton $\mathrm{X}-100,10 \%$ glycerol, $1 \mathrm{mmol} / \mathrm{L}$ sodium vanadate, 10 $\mathrm{nmol} / \mathrm{L}$ microcystin, and $1 \mathrm{mmol} / \mathrm{L}$ phenylmethylsulfonyl fluoride), and $40 \mu \mathrm{g}$ of protein were subjected to SDSpolyacrylamide gel electrophoresis for subsequent immunodetection by blotting on to polyvinylidene difluoride membranes. Membranes were incubated with antibodies for phosphorylated-Smad 2 (1:1000; Cell Signaling), Smad 2 (1:500; Santa Cruz, Inc., Santa Cruz, CA), $\beta 1$ integrin (1:1000; BD Pharmingen, San Jose, CA), and collagen type IV (gift from Dr. Billy Hudson, Vanderbilt University). The immunoblots were visualized by using the enhanced chemiluminescence detection (Amersham, GE Health care, Piscataway, NJ).

\section{RNA Isolation and Real Time Quantitative $R T-P C R$}

RNA was isolated from dermal fibroblasts by using the RNeasy Mini kit (Qiagen, Valencia, CA) according to the manufacturer's instructions. RNA was quantified and reverse transcribed by using the iScript cDNA synthesis kit (Bio-Rad, Hercules, CA) following the manufacturer's instructions. Control reactions in which reverse transcriptase was omitted were included for each sample to confirm the absence of DNA in the RNA sample. Thermal cycling on an iCycler (Bio-Rad) real-time PCR machine was performed by using SYBR supermix (Bio-Rad) in a total volume of $25 \mu \mathrm{l}$, and running for 40 cycles at $95^{\circ} \mathrm{C}$ for 15 seconds and $60^{\circ} \mathrm{C}$ for 1 minute. Quantitation of the results was performed, as previously described, by using the relative standard curve method with control, glyceraldehyde-3-phosphate dehydrogenase expression. ${ }^{19}$ No PCR product was detected in samples in which reverse transcriptase was omitted. Expression of $\alpha 1$ integrin, $\alpha 2$ integrin, $\beta 1$ integrin, collagen type | $\alpha 1$, collagen type । $\alpha 2$, and collagen type III was determine in dermal fibroblasts treated with 4-OH-tamoxifen. The primer sequences are listed in Table 1.

\section{Collagen Gel-Contraction Assay}

The gel contraction assay is based on previously described methods. ${ }^{20}$ Briefly, primary dermal fibroblasts at a density of $10^{5} / \mathrm{ml}$ were suspended in DMEM-F12 and bovine type I collagen. After the suspension gelled in 48-well plates, an equal volume of DMEM-F12 supplemented with $0.5 \%$ FBS was added, and the gels were released with a spatula. The gels were maintained for 3 days in culture medium containing 200 pM TGF- $\beta$ or PBS, and the capacity of the dermal fibroblasts to contract was determined by gel diameter measurement. Medium containing 10\% FBS was used as a positive control. Experiments were performed three times in triplicate.

\section{Immunofluorescence and Confocal Microscopy}

Immunofluorescent staining for actin and VASP was performed on dermal fibroblasts grown on coverslips coated with collagen. Fluorescein isothiocyanate conjugated phalloidin (Sigma-Aldrich, St. Louis, MO) was used to label F-actin in mouse dermal fibroblasts according to the manufacturer's instructions. Briefly, cells were fixed in $3.7 \%$ formaldehyde, washed in PBS, dehydrated in cold acetone, permeabilized with $0.1 \%$ Triton $X-100$, stained with a $50-\mu \mathrm{g} / \mathrm{ml}$ fluorescent phalloidin conjugate solution, washed in PBS, and mounted. VASP was localized by fixing the cells in cold methanol at $-20^{\circ} \mathrm{C}$ for 10 minutes, permeabilized in PBS with $0.3 \%$ NP40 for 10 minutes, and incubated in 10\% FBS blocking buffer with anti-VASP (1:100; Cell Signaling) overnight at $4^{\circ} \mathrm{C}$ followed by incubation with Alexa 488 goat anti-rabbit (1:1000; Invitrogen Corporation, Carlsbad, CA). Slides were examined under a laser scanning confocal microscope (Axiovert 200 M, Carl Zeiss, Jena, Germany) equipped with an LSM510 
META scan head (Carl Zeiss). Argon 488 and heliumneon 543 lasers were used to generate the excitation lines. Z-stacks were collected and images were acquired by using two-line mean averaging in a Z-series typically containing $\mathrm{X}-\mathrm{Y}$ overlapping sections of $0.61 \mu \mathrm{m}$ depth.

\section{Statistical Analysis}

Statistical analysis was performed by using the one-way analysis of variance test for the comparison of multiple variables, and Student's $t$ test was used for comparing two variables. A $P$ value $<0.05$ was considered statistically significant. Results are shown as mean \pm SD. Graphs were generated by using GraphPad Prism version 4 (Graph Software, San Diego, CA).

\section{Results}

\section{TGF- $\beta$ Dermal Responsiveness Mediates Epithelial Wound Closure}

The skin of Tgfbr2 ${ }^{\text {ColTKO }}$ mice was characterized following s.c. injection with 4-OH tamoxifen and oil (control). There were no observable differences in the histology of skin from Tgfbr2 ${ }^{\mathrm{ColTKO}}$ mice injected with oil (Figure 1A) or 4-OH tamoxifen (Figure 1B) compared with wild-type mice by H\&E staining. $\beta$-galactosidase staining was per-

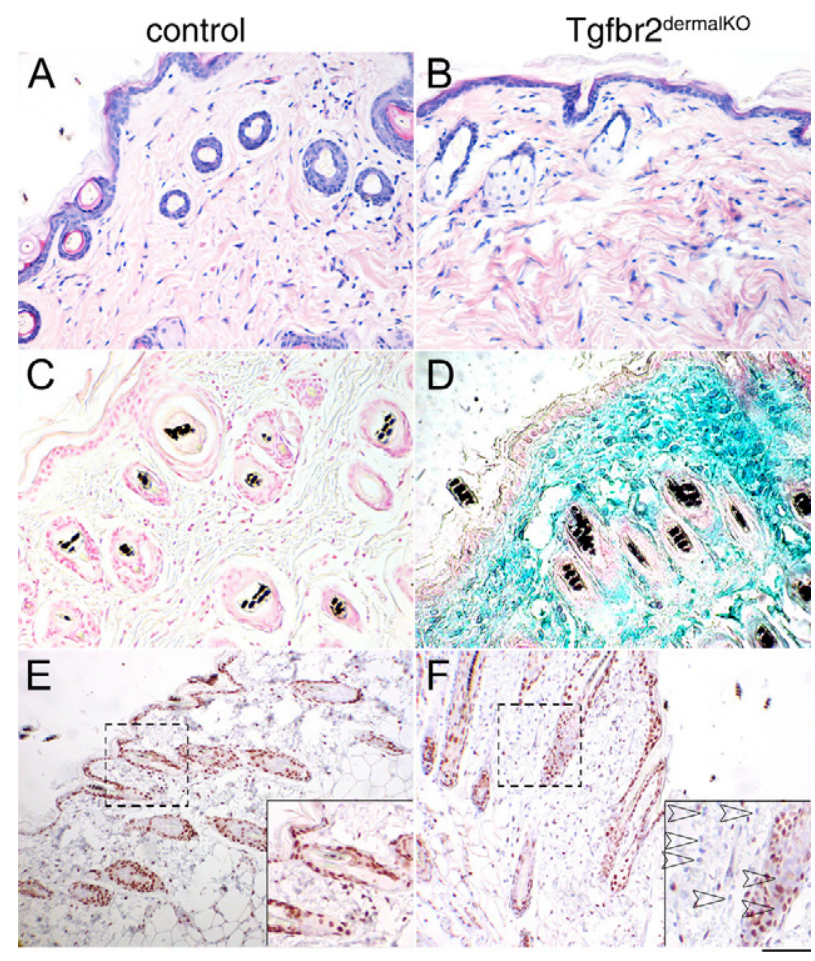

Figure 1. Tgfbr $2^{\text {dermalKO }}$ mice showed Cre-mediated recombination and loss of TGF- $\beta$ responsiveness in the dermis. Histology of back skin from control and Tgfbr $2^{\text {dermalKO }}$ mice was determined by H\&E staining (A and $\left.\mathbf{B}\right) . \beta$-galactosidase activity, associated with DNA recombination, was localized in back skin of control and Tgfbr $2^{\text {dermalKO }}$ mice $(\mathbf{C}$ and $\mathbf{D})$. Immunolocalization for phosphorylated-Smad2, indicating downstream TGF- $\beta$ signaling, had differential expression in dermal fibroblasts of control and Tgfbr2dermalko mice $(\mathbf{E}$ and $\mathbf{F})$. Scale bars: $20 \mu \mathrm{m}(\mathbf{A}-\mathbf{F}) ; 10 \mu \mathrm{m}$ (dashed area magnified in inset). formed to visualize Cre-mediated recombination in the stroma. Control Tgfbr2 ${ }^{\text {ColTKO }}$ mice showed no positive staining for $\beta$-galactosidase (Figure $1 \mathrm{C}$ ). Tgfbr2 ${ }^{\mathrm{ColTKO}}$ mice injected with 4-OH tamoxifen were positive for $\beta$-galactosidase in the dermis, indicating that Cre-mediated recombination occurred in the stroma and not in the epithelium (Figure 1D). Immunohistochemical localization of phosphorylated-Smad2 was performed to determine the status of TGF- $\beta$ signaling activity in the dermis. Control Tgfbr2 ${ }^{\text {ColTKO }}$ mice had nuclear localization of phosphorylated-Smad2 (brown nuclei, Figure 1E) in nearly all cells in the skin, whereas Tgfbr2 ${ }^{\text {ColTKO }}$ mice injected with 4-OH tamoxifen had few dermal fibroblasts with phosphorylated-Smad2 expression (blue nuclei, Figure 1F). However, hair follicle-lining cells and keratinocytes from Tgfbr2 ${ }^{\mathrm{ColTKO}}$ mice injected with $4-\mathrm{OH}$ tamoxifen displayed TGF- $\beta$ signaling, as indicated by positive phosphorylated-Smad2 staining. It is important to note there are many cell types in the dermal compartment, only those cells expressing collagen $1 \alpha 2$ would have the capacity to mediate Cre-mediated Tgfbr2 DNA recombination after 4-OH-tamoxefin injection. The inducible, conditional Tgfbr2 ${ }^{\text {ColTKO }}$ mice are referred to as Tgfbr2 ${ }^{\text {dermalkO }}$ or control when injected subcutaneously with $4-\mathrm{OH}$ tamoxefin or oil, respectively.

TGF- $\beta$ has an important role in the regulation of wound healing and tissue repair. ${ }^{21}$ We tested the role of TGF- $\beta$ signaling in dermal fibroblasts in full thickness 4-mm excisional wounds. Control and Tgfbr2 ${ }^{\text {dermalko }}$ mice healing were followed up to 14 days after wounding. At 4 days after injury, Tgfbr2 ${ }^{\text {dermalko }}$ skin wounds showed little contraction and a reduced organization of granulation tissue when compared with controls (Figure 2A). However, wounds from Tgfbr ${ }^{\text {dermalKO }}$ mice showed significantly accelerated re-epithelization when compared with control wounds (Table 2). Because dominant mechanism of wound closure in mice is contraction, a metal washer was fixed to the skin immediately after wounding to limit contraction in further studies of re-epithelization. ${ }^{22}$ The H\&E-stained paraffin sections, representing the longitudinal diameter of the wound, showed minimal reepithelization in control wounds at 4 days (Figure 2B). In comparison, Tgfbr2dermalko wounds had complete reepithelization in the same period of time but a less complete formation of granulation tissue. The injection of either oil or $4-\mathrm{OH}$ tamoxifen 7 days before wounding of wild-type mice produced no observable differences in the rate or quality of repair (data not shown).

Re-epithelization was visualized by keratin 5 immunohistochemical staining of the basal layer of the epidermis. The loss of TGF- $\beta$ responsiveness in dermal fibroblasts resulted in increased abundance of keratin 5-positive keratinocytes in a hypertrophic epidermis and evidence of suprabasal expression of keratin 5 (Figure 2C). To examine the role of proliferation in the accelerated re-epithelization of Tgfbr2 ${ }^{\text {dermalkO }}$ mice, cell proliferation was assessed by immunolocalization of Ki-67. Control mice showed keratinocyte proliferation at the distal wound edges (Figure 2D). However, wounds on Tgfbr2 ${ }^{\text {dermalKO }}$ mice exhibited keratinocyte proliferation extending over the entire wound surface. Accordingly, 


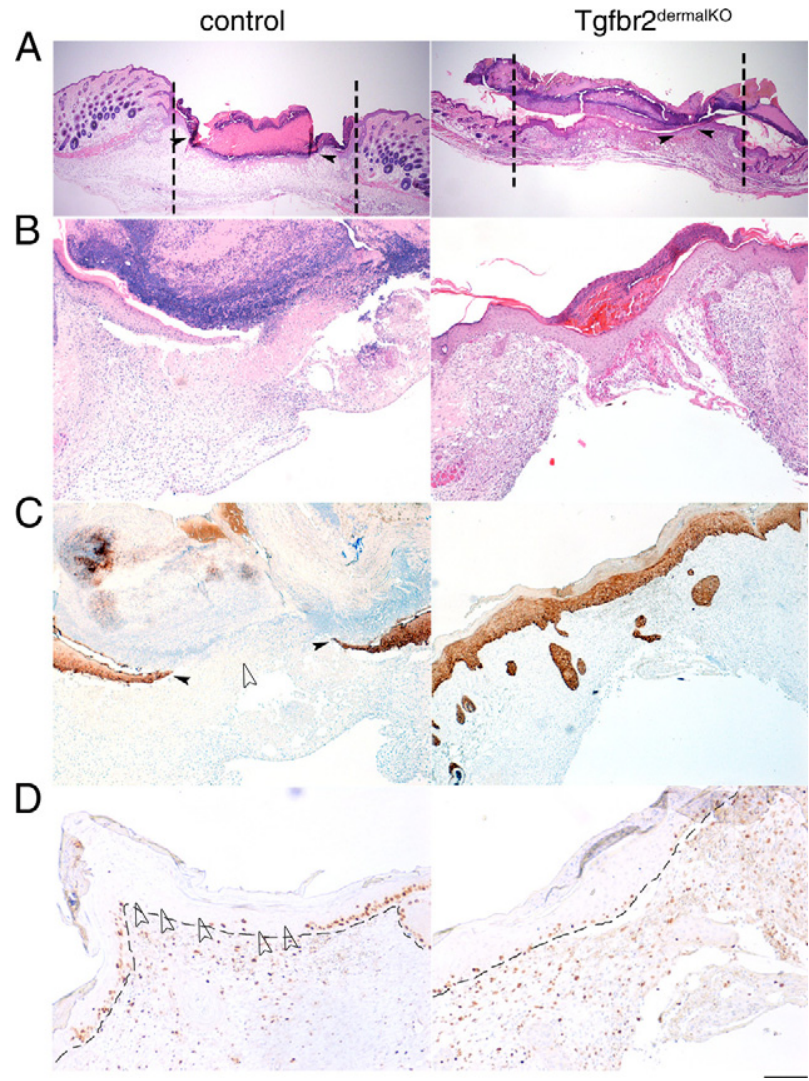

Figure 2. Wounding of Tgfbr $2^{\text {dermalKO }}$ and control skin result in differential contraction and re-epithelization. Full thickness excisional wounds were made on the shaved back of 6- to 8-week-old Tgfbr $2^{\text {dermalKO }}$ and control mice, and healing was examined. Four days after wounding, the control and Tgfbr $2^{\text {dermalko }}$ mice healed with dermal contraction (vertical dotted lines indicate wound edge) and re-epithelization (A). To limit wound contraction, washers were implanted for the subsequent wounds. H\&E staining revealed differential re-epithelization in control and Tgfbr $2^{\text {dermalKO }}$ mice after 4 days of healing (B). Keratin 5 staining indicated abundance of keratinocytes covering the wound with stark differences in control and Tgfbr $2^{\text {dermalko }}$ mice $(\mathbf{C})$. The epithelial compartment indicated by the dashed line of control and Tgfbr $2^{\text {dermalKO }}$ wounds had similar keratinocyte Ki-67 positive staining at the distal wound edges. Tgfbr $2^{\text {dermalKo }}$ wounds had elevated keratinocyte proliferation at the center of wound compared with control wounds (D) Filled arrowheads indicate leading edge of epithelia. Empty arrowheads indicate area lacking immunohistochemical staining. Scale bars: $400 \mu \mathrm{m}$ (A); $20 \mu \mathrm{m}$ (B and $\mathbf{C}) ; 10 \mu \mathrm{m}(\mathbf{D})$.

the loss of dermal TGF- $\beta$ responsiveness resulted in accelerated re-epithelization of wounds associated with decreased dermal contraction.

\section{TGF- $\beta$ Dermal Responsiveness Differentially Affects Granulation Tissue Formation}

TGF- $\beta$ signaling has been implicated in multiple roles in wound healing, including collagen deposition and myo-

Table 2. Effect of the Loss of Dermal TGF- $\beta$ Signaling on Day 4 of Wound Re-Epithelization

\begin{tabular}{lcc}
\hline \multicolumn{1}{c}{ Strain } & $n$ & $\begin{array}{c}\text { Percent } \\
\text { re-epithelization }\end{array}$ \\
\hline Control & 8 & $22.5 \pm 2.5$ \\
Tgfbr2 $^{\text {dermalko }}$ & 8 & $58.0 \pm 2.9^{*}$ \\
\hline
\end{tabular}

Each value represents mean \pm SE. Original magnification, $\times 1000$. ${ }^{\star} P<0.001$ versus control.

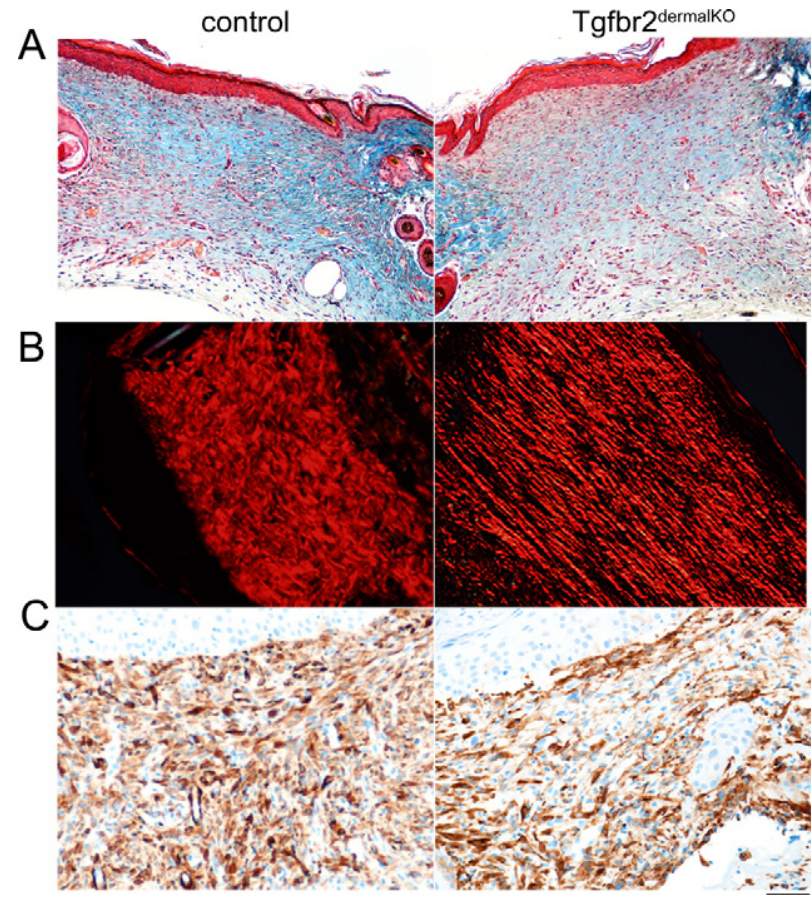

Figure 3. Dermal TGF- $\beta$ signaling mediates extracellular matrix deposition and organization. Tgfbr $2^{\text {dermalko }}$ mice had less collagen deposition 14 days after wounding when compared with control mice based on Masson's Trichrome blue staining (A). Collagen fiber organization was visualized by picrosirius red staining and polarized light microscopy. The birefringent collagen fibers in control 14-day wounds had a woven architecture through the span of the wound similar to adjacent nonwounded areas, while Tgfbr $2^{\text {dermalKO }}$ wounds had less refractile collagen fibers in nearly parallel fiber architecture (B). Wounds of control and Tgfbr $2^{\text {dermalKO }}$ mice had similar $\alpha$-smooth muscle actin immunohistochemical staining (C). Scale bars: $40 \mu \mathrm{m}$ (A); $20 \mu \mathrm{m}$ (B and $\mathbf{C}$ ).

fibroblastic differentiation as important components of granulation tissue formation. ${ }^{23-27}$ In examining collagen deposition in skin wounds, sections stained with Masson's trichrome suggested wounds on Tgfbr2 $2^{\text {dermalkO }}$ mice had less collagen deposition at day 14 after wounding, compared with control mice (Figure 3A). As a measure of collagen fiber orientation, wounds stained with picrosirius red were observed with polarized light microscopy. Collagen in control mice had abundant, refractile fibers in a woven architecture throughout the 14-day wound, similar to adjacent nonwounded areas (Figure 3B). However, wounds on Tgfbr2 ${ }^{\text {dermalkO }}$ mice had fewer refractile collagen fibers compared with control mice with nearly parallel fiber architecture. The adjacent nonwounded areas in the skin of Tgfbr2 ${ }^{\text {dermalko }}$ mice maintained collagen fiber organization similar to control mice. Quantitation of picrosirius red staining indicated a statistically greater collagen expression in control compared with Tgfbr2 ${ }^{\text {dermalKO }}$ wounds $(18.1 \pm 3.2$ and $11.0 \pm 3.1$, respectively, $P=0.004$; values indicate mean $\pm \mathrm{SD})$. The lack of collagen maturation by 14 days in Tgfbr2 ${ }^{\text {dermalko }}$ reinforced the concept that dermal TGF- $\beta$ signaling in the stroma potentiates both deposition and maturation of collagen in wound healing. Myofibroblasts are thought to be a transient differentiation state associated with wound healing and are attributed to collagen maturation. The authors of in vitro studies suggest TGF- $\beta$ to be the medi- 


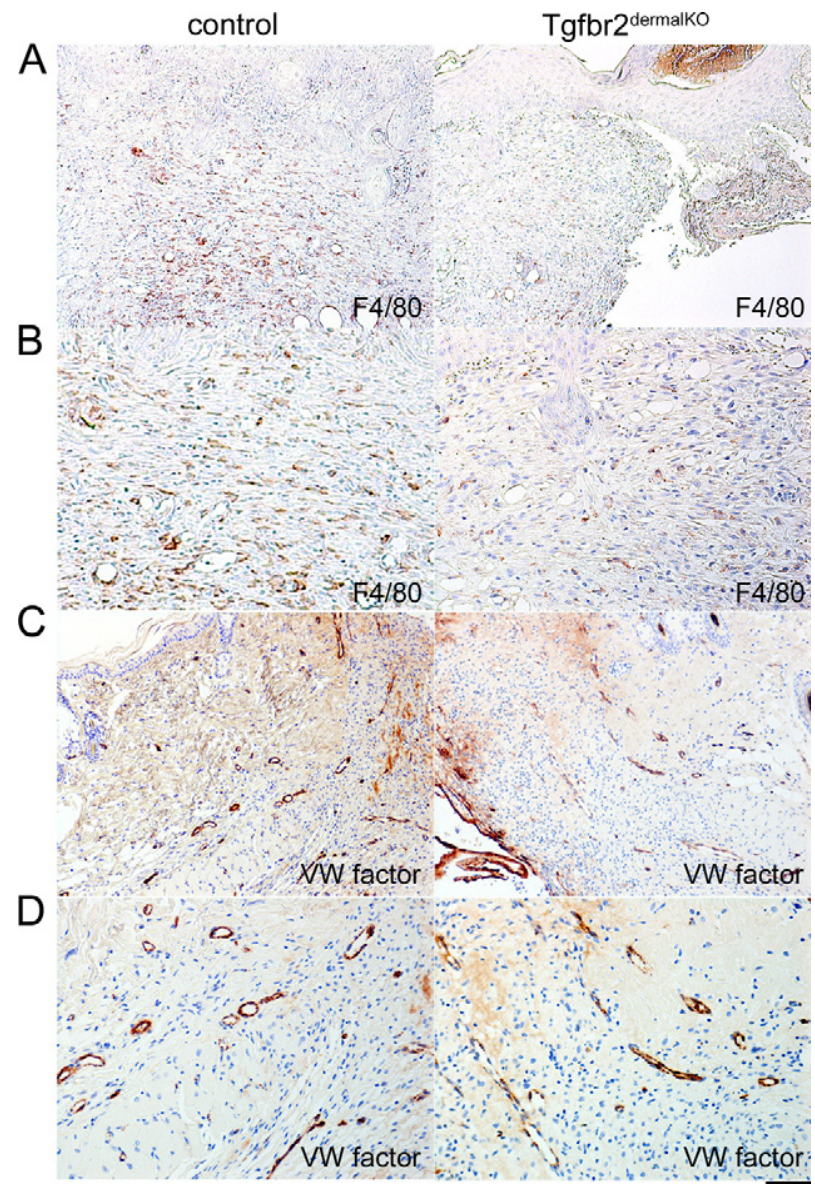

Figure 4. Dermal TGF- $\beta$ signaling mediates inflammatory infiltration of wounds. Macrophage infiltration was attenuated in the Tgfbr2 $2^{\text {dermalKO }}$ wounds compared with control localized, as localized by immunohistochemistry for $\mathrm{F} 4 / 80$ expression ( $\mathbf{A}$ and $\mathbf{B} ; P<0.003$ ). However, vasculature density did not significantly differ between the control and Tgfbr $2^{\text {dermalKO }}$ wounds as determined by endothelial cell staining by Von Willebrand (WV) factor VIII expression (C and D). Scale bars: $40 \mu \mathrm{m}(\mathbf{A}$ and $\mathbf{C}) ; 20 \mu \mathrm{m}$ (B and $\mathbf{D})$

ator of myofibroblastic differentiation. ${ }^{28-30}$ However, wounds of control and Tgfbr2 ${ }^{\text {dermalkO }}$ mice had similar $\alpha$-smooth muscle actin expression (Figure 3C).

We further analyzed the extent of inflammatory infiltrates and neovascularization in granulation tissue. The control wounds recruited significantly greater numbers of F4/80-positive macrophages than wounds in Tgfbr2 $^{\text {dermalkO }}$ skin $(21.5 \pm 0.5$ and $7.3 \pm 0.6$, respectively, $P<0.003$; values indicate mean $\pm \mathrm{SE}$ ) (Figure 4, $A$ and $B$ ). Angiogenesis was assessed by immunohistochemical staining for von Willebrand factor VIII. No significant difference was found in vessel density between the control and Tgfbr2 ${ }^{\text {dermalko }}$ wounds (Figure 4, C and D). These results would indicate that TGF- $\beta$ signaling by the dermal fibroblasts predominantly mediated collagen deposition and organization while not having a rate-limiting role in stromal differentiation. Reduced TGF- $\beta$ signaling suppressed mononuclear cell recruitment in granulation tissue, which likely diminished the expression of other paracrine signals.

\section{Extracellular Matrix and Cytoskeletal Organization Mediated by TGF- $\beta$ Signaling}

The remodeling phase of wound healing is characterized by wound contraction due to the action of fibroblasts. Dermal fibroblasts from both control and Tgfbr2 $2^{\text {dermalkO }}$ wounds had similar myofibroblastic conversion, yet they had vastly different contractile properties. Myofibroblasts have dense arrays of $\alpha$-smooth muscle actin filaments that crosslink with myosin to produce tension. To measure the contractile capacity in the context of an identical matrix environment, cultured primary dermal fibroblasts from control and Tgfbr2 ${ }^{\text {dermalkO }}$ mice were embedded in collagen I gels. The gel diameter was measured after 3 days of incubation in media containing $10 \%$ serum. Tgfbr2 ${ }^{\text {dermalkO }}$ fibroblasts had markedly reduced gel contraction compared with control fibroblasts (Figure $5 \mathrm{~A}$ ). The Tgfbr2 ${ }^{\text {dermalkO }}$ fibroblasts mediated 3.4-fold less gel contraction than that mediated by control fibroblasts $(P<0.0001)$. These results corroborated previous reports that TGF- $\beta$ mediates contraction by fibroblasts in vitro $^{31-33}$; however, reduced collagen accumulation may have been a secondary factor in the observed reduction in wound contraction in the Tgfbr2 ${ }^{\text {dermalko }}$ wounds.

TGF- $\beta$ signaling in cultured cells was examined by Western blotting of protein extracts from control and Tgfbr2 ${ }^{\text {dermalkO }}$ fibroblasts treated with or without TGF- $\beta 1$ for 6 hours. As expected, control fibroblasts had elevated phosphorylated-Smad2 expression when treated with TGF- $\beta 1$ (Figure 5B), while Tgfbr2 ${ }^{\text {dermalKO fibroblasts had }}$ little phosphorylated-Smad2 activation, based on similar expression levels of total Smad2. However, $\beta 1$ integrin expression was up-regulated by TGF- $\beta 1$ in the control

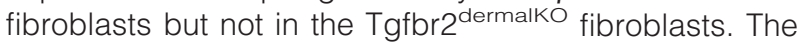
expression of basement membrane collagen type IV expression was similar in all cell extracts. The lack of integrin induction by the Tgfbr2 ${ }^{\text {dermalKO }}$ fibroblasts could certainly contribute to the reduced dermal contraction observed in the wounds.

To further confirm the involvement of specific integrins and collagen, cultured cells were examined by real time RT-PCR of mRNA from control and Tgfbr2 ${ }^{\text {dermalkO fibro- }}$ blasts. Integrins are transmembrane proteins that form $\alpha \beta$ heterodimers and act as receptors for extracellular matrix proteins. ${ }^{34}$ Integrins are also critical in keratinocyte adhesion and migration, ${ }^{34}$ and they are the principal means of transducing forces and signals between the cytoplasm and the extracellular matrix in mesenchymal cells by linking the extracellular environment to the actin cytoskeleton via connections with adaptor proteins such as talin and filamin. ${ }^{35}$ The expression of $\alpha 1$ integrin, $\alpha 2$ integrin, and $\beta 1$ integrin, which constitute the principal collagen receptors, was significantly decreased+ in Tgfbr2 dermalkO fibroblasts compared with control by 3.5-fold $(P<0.001)$, 2.1-fold $(P<0.001)$, and 2.1-fold $(P<0.001)$, respectively (Figure 5C). COL1A1 and COL1A2 expression were reduced by 3.5-fold $(P<$ 0.001 ) and 2.7-fold $(P<0.001)$, respectively (Figure 5D). In addition, COL3A1 mRNA expression was significantly $(P<0.001)$ reduced by 4.4 -fold in Tgfbr2 ${ }^{\text {dermalKO }}$ fibro- 
A
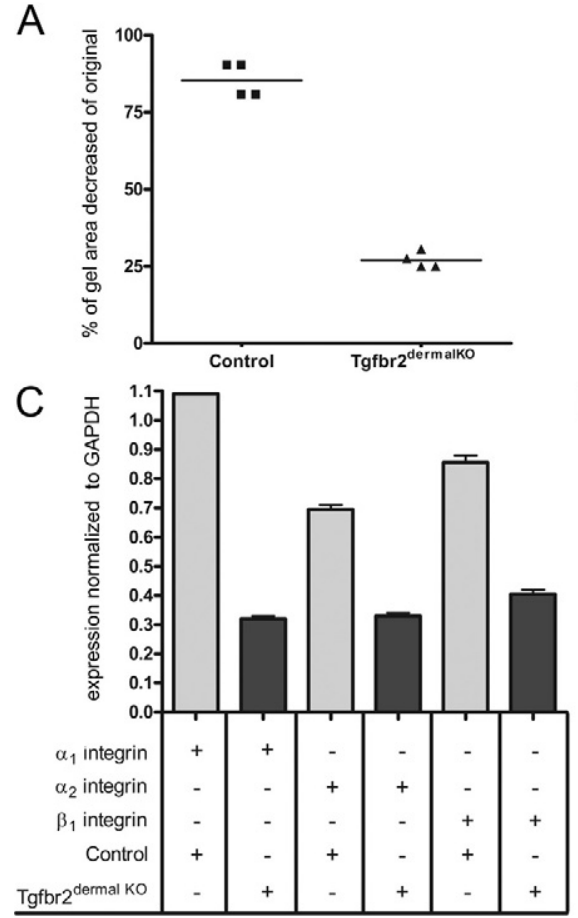

B
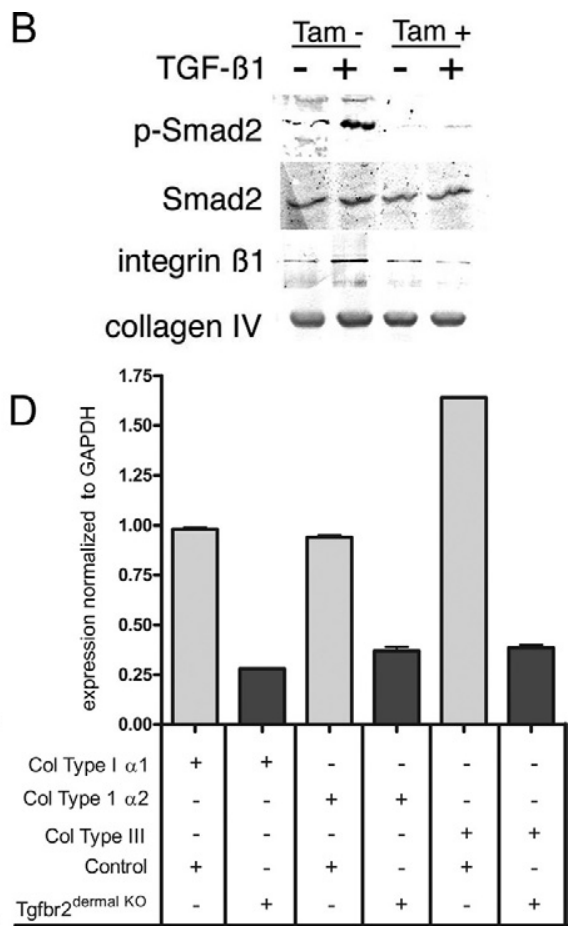

Figure 5. TGF- $\beta$ signaling mediates dermal contraction. Control and Tgfbr $2^{\text {dermalKO }}$ dermal fibroblasts had significantly different in vitro collagen I gel contractile ability after 3 days of culture (mean indicated by line, $P<0.0001)(\mathbf{A})$. Cells treated with or without TGF- $\beta$ for 6 hours were examined by Western blotting to determine the activation of Smad 2, expression of $\beta 1$ integrin, and collagen type IV (B). Real time RT-PCR indicated mRNA expression of $\alpha 1$ integrin, $\alpha 2$ integrin, and $\beta 1$ integrin $(\mathbf{C})$; and collagen type I $\alpha 1$, collagen type I $\alpha 2$, and collagen type III (D). Control fibroblast expression (light colored bars) had generally greater integrin and collagen isoform expression compared with that of Tgfbr2 $2^{\text {dermalKO }}$ fibroblasts (dark bars). Error bars indicate $\mathrm{SD}(n=3)$ blasts compared with control (Figure 5D). Thus, the loss of dermal TGF- $\beta$ responsiveness inhibited dermal contraction in vivo and in vitro. The contractile phenotype correlated with dermal collagen organization and fibroblastic expression of interstitial collagens and their integrin receptors.

Reorganization of the actin cytoskeleton is a fundamental process during wound remodeling. To observe F-actin distribution and stress fiber development, control and Tgfbr2 ${ }^{\text {dermalkO }}$ fibroblasts were grown on collagen I coated coverslips and stained with phalloidin. As expected, extensive arrays of F-actin fibers were present in control dermal fibroblasts, while F-actin distribution and development were diminished in Tgfbr2 ${ }^{\text {dermalKO fibro- }}$ blasts (Figure 6). VASP is associated with filamentous actin formation, cell adhesion, and motility. ${ }^{4}$ Confocal microscopy revealed markedly diminished lamellipodia

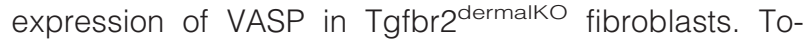
gether, the data emphasize the importance of dermal TGF- $\beta$ responsiveness in promoting wound remodeling through the interdependent processes of extracellular matrix organization, integrin expression, and intracellular cytoskeletal organization.

\section{Discussion}

Paracrine signaling universally mediates stromal-epithelial interactions in cancer initiation, development, and wound healing. In contrast to typical mouse skin wounds, the Tgfbr2 ${ }^{\text {dermalko }}$ excisional wounds healed by re-epithelization rather than wound contraction and granulation tissue formation. To isolate the first process, we fixed metal stents to the wound periphery. This model limited the contractile response and facilitated the study of re- epithelization. We found that loss of TGF- $\beta$ responsiveness in the wounded dermis potentiated the proliferation and migration of the adjacent keratinocytes as the wound re-epithelized. The postnatal knockout of dermal TGF- $\beta$ signaling did not affect the histological organization of intact skin, but neodermis was markedly altered in syn-

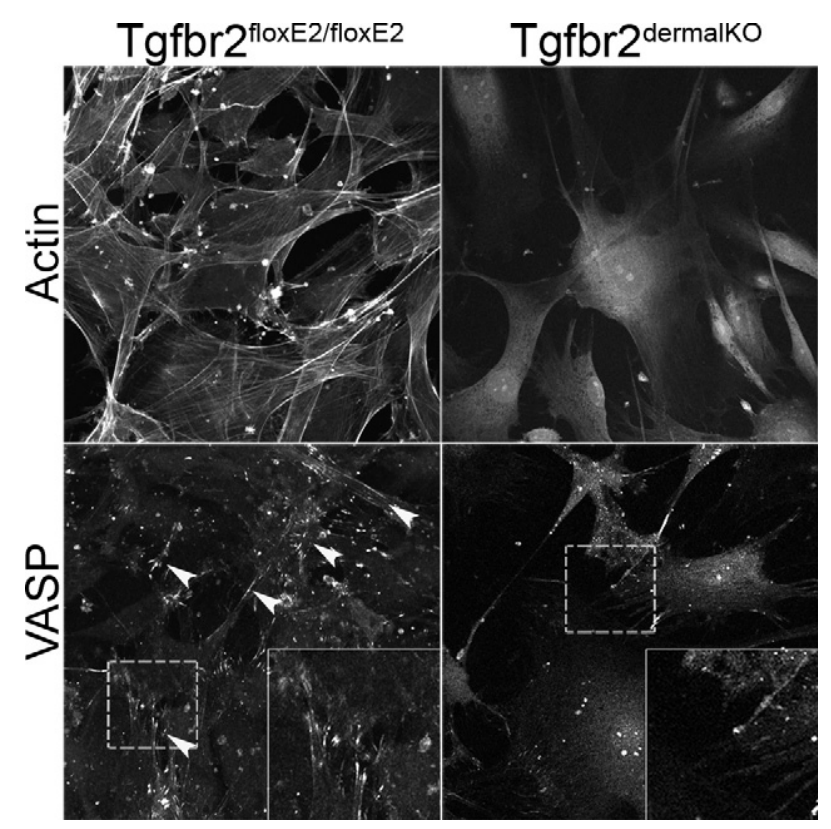

Figure 6. Confocal fluorescent microscopy localized actin and VASP in control and Tgfbr $2^{\text {dermalKo }}$ dermal fibroblasts grown on collagen-coated coverslips. Actin stress fibers were reduced in Tgfbr $2^{\text {dermalKo }}$ fibroblasts when compared with control. VASP expression was diminished in Tgfbr $2^{\text {dermalKO }}$ fibroblasts when compared with control. Arrowheads indicate VASP localization at lamellipodia in control fibroblasts. Insets reflect a higher magnification of the area in the dashed boxes. 
thetic and contractile properties. The Tgfbr2 $2^{\text {dermalkO }}$ mouse model revealed the paracrine role of TGF- $\beta$ signaling in re-epithelization of the wound.

Adult skin wound healing involves overlapping phases of acute inflammation, rapid proliferation of epithelial and dermal cells, and the formation of a persistent scar, while embryonic and fetal skin wound healing is rapid, with minimal inflammation, and it is scarless. ${ }^{36,37}$ During development of mouse skin, the transition from scarless to fibrotic healing occurs after embryonic day 16. Intrinsic differences between fetal and adult fibroblasts can influence the quality of wound repair. ${ }^{38}$ Scarless healing in regenerating fetal skin has been attributed, in part, to the lack of dermal TGF- $\beta$ signaling. ${ }^{39,40}$ While this article was in review, Denton et al ${ }^{39}$ reported a similar, conditional knockout of Tgfbr2 in dermal fibroblasts, where excisional wounding resulted in a phenotype similar to the Tgfbr2 ${ }^{\text {dermalKO }}$ phenotype, characterized by reduced and delayed dermal collagen organization and elevated epidermal proliferation. Changes in macrophage recruitment was not noted, but the authors suggested that myofibroblast abundance could have been due to differentiation of bone marrow-derived fibrocytes. ${ }^{39,41}$ Importantly, human and mouse wound healing differ in that mouse skin produces little scar tissue because dermal contraction is the predominant mechanism of wound closure. Many investigators have proposed that the acquisition of dermal TGF- $\beta$ signaling later in embryogenesis anticipates scarring in adults. Indeed, induction of TGF- $\beta$ in fetal dermis produces precocious scarring. ${ }^{42}$ We developed transgenic mice that have an inducible, conditional knockout of the TGF- $\beta$ type II receptor in dermal fibroblasts in the hope of mimicking the embryonic wound healing phenotype. The Tgfbr2 ${ }^{\text {dermalko }}$ adult mice exhibited accelerated re-epithelization, reduced inflammatory cell recruitment, and deficient dermal collagen re-organization (Figures 2-4).

Wound healing is classically characterized by the transient development of granulation tissue that supports rapid proliferation, migration, and differentiation of the adjacent epithelium. ${ }^{43}$ The transient reactive stroma includes vascularization of the wound, infiltration of inflammatory cells, and differentiation of the dermal fibroblasts. Vascularity (determined by von Willebrand factor VIII expression by endothelial cells) was not significantly altered in the Tgfbr2 ${ }^{\text {dermalkO }}$ compared with the control wounds. However, macrophage infiltration (F4/80 expression) was nearly absent at 7 days of wounding in the Tgfbr2 $2^{\text {dermalkO }}$ wounds relative to control wounds. The Smad3 transgenic knockout wound healing model, in which TGF- $\beta$ signaling is attenuated, was reported to have a similar decrease in inflammatory infiltration. ${ }^{6}$ Although TGF- $\beta$ appears to be immunosuppressive in immune cells per se, its chemotactic activity at low concentrations promote inflammatory infiltration during wound healing. ${ }^{44-46}$ The previously reported SMAD3 knockout mouse also exhibited a markedly reduced inflammatory response after skin wounding. ${ }^{47,48}$ The Tgfbr2 ${ }^{\text {dermalKO }}$ mouse model suggests the wound-associated inflammatory response to be a result of dermal TGF- $\beta$ responsiveness.
The granulation tissue is associated with the differentiation of dermal fibroblasts into myofibroblasts. This process, which involves the co-expression of vimentin and $\alpha$-smooth muscle actin, is often attributed to TGF- $\beta$ signaling. However, the loss of TGF- $\beta$ responsiveness in the stromal fibroblasts did not seem to alter myofibroblastic differentiation of the dermis. Denton et $\mathrm{al}^{39}$ recently reported that the myofibroblasts in the conditional knockout wound were also CD34-positive, suggestive of bone marrow origin. Although inflammation can be coupled with myofibroblastic differentiation, ${ }^{47-49}$ this association did not seem to be true in the Tgfbr2 ${ }^{\text {dermalko }}$ mice. The wounds did not recruit monocytes, yet they had myofibroblastic enrichment. It is possible that an alternative activation of connective tissue growth factor may contribute to this phenomenon. ${ }^{39}$ Wound contraction is frequently associated with myofibroblastic differentiation, and it is well established that contraction is the main mechanism by which many loose-skinned animals close full-thickness wounds. ${ }^{50}$ Contraction was not observed in Tgfbr2 ${ }^{\text {dermalKO }}$ skin or in isolated Tgfbr2-KO dermal fibroblasts. The loss of $\beta 1$ integrin expression and lack of collagen organization are two likely mechanisms by which contraction may be uncoupled in the Tgfbr2 $2^{\text {dermalko }}$ skin, despite the clear myofibroblastic differentiation-expression of $\alpha$-smooth muscle actin. Dermal contraction requires that (myo)fibroblasts have a means of coupling to the extracellular matrix, and proper matrix interaction is required for concerted cellular movement into and within the wound space. Matrix binding and contractility are interdependent because collagen organization in part requires cellular tension. The observations made in Tgfbr2 ${ }^{\text {dermalko }}$ skin wound healing suggest that the role for TGF- $\beta$ dermal responsiveness in terms of vascularization and myofibroblastic differentiation has redundant mechanisms, possibly related to the participation of marrow-derived progenitor populations. The bone marrow contributes significantly to the formation of granulation tissue through the recruitment of fibrocytes and marrowderived fibroblast progenitors. ${ }^{41}$ If $\mathrm{COL} 1 \mathrm{~A} 2$ expression was inactive in these cells at the time of tamoxifen administration, they may have escaped inactivation and thus contributed to the $\alpha$-smooth muscle actin-positive myofibroblast population. If these circulating cells were TGF- $\beta$ responsive, one might expect a capacity to compensate for loss of dermal fibroblast collagen production. However, dermal TGF- $\beta$ responsiveness is necessary for inflammatory cell recruitment and wound contraction in the healing process.

In an attempt to establish the mechanism by which

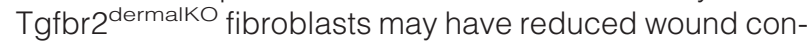
traction, the expression of integrins and cytoskeletal proteins was studied. Previous studies have shown that mice lacking $\beta_{3}$ integrin had accelerated re-epithelization compared with wild-type mice. ${ }^{51}$ Reports from Grenache et $a l,{ }^{52}$ Zweers et $a{ }^{153}$ and Parks ${ }^{54}$ indicated that skin develops normally in mice deficient in the $\alpha 2$-integrin subunit. In those mouse models, the authors found changes in other $\beta 1$ integrins that may compensate for the loss of the $\alpha_{2} \beta_{1}$ integrin. The loss of TGF- $\beta$ signaling may well have prevented the activation of compensatory 
adhesion receptors. In our model, the loss of Smad activation was associated with decreased expression of integrins, an alteration of F-actin distribution and decreased expression of VASP. Marked morphological alterations of actin stress fibers and VASP expression localization may be associated with reduction in contrac-

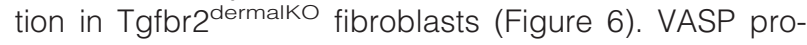
teins are involved in numerous processes regulated by actin, ${ }^{4}$ including promotion of actin filament elongation. ${ }^{55}$ Wounding induces the activation of focal adhesion proteins and integrins. ${ }^{35}$ The loss in the expression of $\alpha 1$ integrin, $\alpha 2$ integrin, $\beta 1$ integrin, actin stress fibers, and lamellipodia-associated VASP by Tgfbr2 ${ }^{\text {dermalkO }}$ skin fibroblasts can be the rationale for both the lack of mature collagen organization and dermal contraction.

The mechanisms whereby ablation of mesenchymal TGF- $\beta$ signaling lead to enhanced epithelization are not well understood. The authors of previous studies of the Smad3 null phenotype in skin and lens wounds had enhanced epithelization. ${ }^{6-8}$ Possible mechanisms for the elevated epithelialization is increased proliferation or motility. Because TGF- $\beta$ itself can regulate both mechanisms and the positive feed-back loop of TGF- $\beta$ expression may be disrupted by the knockout of Tgfbr2 in the dermal fibroblasts, we examined the expression of the three TGF- $\beta$ isoforms as well as hepatocyte growth factor and connective tissue growth factor. Apparently, knocking out TGF- $\beta$ signaling does not seem to inhibit the expression of the TGF- $\beta 1$ and TGF- $\beta 3$ ligands or the expression of hepatocyte growth factor and connective tissue growth factor (see Supplemental Figure S1 at http://ajp.amjpathol.org). But, we found a significant decrease in TGF- $\beta 2$ expressed by Tgfbr2 knocked out fibroblasts. The relevance of the reduction of TGF- $\beta 2$ in light of similar levels of the other two isoforms of TGF- $\beta$ is not known. However, it is important to revisit our data in Figure 2D where we found that there was no significant difference in proliferation of the epithelia. So, a likely mechanism for accelerated re-epithelialization is increased motility of the keratinocytes. Together, it seems the specific role of dermal TGF- $\beta$ responsiveness in wound healing involves the recruitment of macrophage, wound contraction, and epithelial motility. The mechanism for dermal contraction is likely a direct result of TGF- $\beta$ signaling. However, the paracrine mechanisms re-epithelialization and macrophage recruitment remain unclear in our mouse model.

\section{References}

1. Ichijima H, Petroll WM, Barry PA, Andrews PM, Dai M, Cavanagh HD, Jester JV: Actin filament organization during endothelial wound healing in the rabbit cornea: comparison between transcorneal freeze and mechanical scrape injuries. Invest Ophthalmol Vis Sci 1993, 34:2803-2812

2. Salazar R, Bell SE, Davis GE: Coordinate induction of the actin cytoskeletal regulatory proteins gelsolin, vasodilator-stimulated phosphoprotein, and profilin during capillary morphogenesis in vitro. Exp Cell Res 1999, 249:22-32

3. Cowin AJ, Adams D, Geary SM, Wright MD, Jones JC, Ashman LK: Wound healing is defective in mice lacking tetraspanin CD151. J Invest Dermatol 2006, 126:680-689

4. Grosse R, Copeland JW, Newsome TP, Way M, Treisman R: A role for
VASP in RhoA-Diaphanous signalling to actin dynamics and SRF activity. EMBO J 2003, 22:3050-3061

5. Roberts AB: Transforming growth factor-beta: activity and efficacy in animal models of wound healing. Wound Repair Regen 1995, 3:408-418

6. Ashcroft GS, Yang X, Glick AB, Weinstein M, Letterio JL, Mizel DE, Anzano M, Greenwell-Wild T, Wahl SM, Deng C, Roberts AB: Mice lacking Smad3 show accelerated wound healing and an impaired local inflammatory response. Nat Cell Biol 1999, 1:260-266

7. Flanders KC, Major CD, Arabshahi A, Aburime EE, Okada MH, Fujii M, Blalock TD, Schultz GS, Sowers A, Anzano MA, Mitchell JB, Russo A, Roberts $\mathrm{AB}$ : Interference with transforming growth factor-beta/ Smad3 signaling results in accelerated healing of wounds in previously irradiated skin. Am J Pathol 2003, 163:2247-2257

8. Saika S, Kono-Saika S, Ohnishi Y, Sato M, Muragaki Y, Ooshima A, Flanders KC, Yoo J, Anzano M, Liu CY, Kao WW, Roberts AB: Smad3 signaling is required for epithelial-mesenchymal transition of lens epithelium after injury. Am J Pathol 2004, 164:651-663

9. Bullard KM, Longaker MT, Lorenz HP: Fetal wound healing: current biology. World J Surg 2003, 27:54-61

10. Bleacher JC, Adolph VR, Dillon PW, Krummel TM: Fetal tissue repair and wound healing. Dermatol Clin 1993, 11:677-683

11. Kim JE, Nakashima K, de Crombrugghe B: Transgenic mice expressing a ligand-inducible cre recombinase in osteoblasts and odontoblasts: a new tool to examine physiology and disease of postnatal bone and tooth. Am J Pathol 2004, 165:1875-1882

12. Zheng B, Zhang Z, Black CM, de Crombrugghe B, Denton CP: Ligand-dependent genetic recombination in fibroblasts: a potentially powerful technique for investigating gene function in fibrosis. Am J Pathol 2002, 160:1609-1617

13. Chytil A, Magnuson MA, Wright CV, Moses HL: Conditional inactivation of the TGF-beta type II receptor using Cre:Lox. Genesis 2002, 32:73-75

14. Soriano P: Generalized lacZ expression with the ROSA26 Cre reporter strain. Nat Genet 1999, 21:70-71

15. Placencio VR, Sharif-Afshar AR, Li X, Huang H, Uwamariya C, Neilson EG, Shen MM, Hayward SW, Matusik RJ, Bhowmick NA: Stromal TGF- $\beta$ signaling mediates prostatic androgen response by paracrine Wnt activity. Cancer Res 2008, 68:4709-4718

16. Koren R, Yaniv E, Kristt D, Shvero J, Veltman V, Grushko I, Feinmesser R, Sulkes J, Gal R: Capsular collagen staining of follicular thyroid neoplasms by picrosirius red: role in differential diagnosis. Acta Histochem 2001, 103:151-157

17. Low QE, Drugea IA, Duffner LA, Quinn DG, Cook DN, Rollins BJ, Kovacs EJ, DiPietro LA: Wound healing in MIP-1alpha $(-/-)$ and MCP-1(-/-) mice. Am J Pathol 2001, 159:457-463

18. Mori R, Kondo T, Ohshima $\mathrm{T}$, Ishida $\mathrm{Y}$, Mukaida $\mathrm{N}$ : Accelerated wound healing in tumor necrosis factor receptor p55-deficient mice with reduced leukocyte infiltration. FASEB J 2002, 16:963-974

19. Martinez-Ferrer M, Iturregui JM, Uwamariya C, Starkman J, SharifAfshar AR, Suzuki K, Visedsindh W, Matusik RJ, Dmochowski RR, Bhowmick NA: Role of nicotinic and estrogen signaling during experimental acute and chronic bladder inflammation. Am J Pathol 2008, 172:59-67

20. Zent R, Ailenberg M, Waddell TK, Downey GP, Silverman M: Puromycin aminonucleoside inhibits mesangial cell-induced contraction of collagen gels by stimulating production of reactive oxygen species. Kidney Int 1995, 47:811-817

21. Martin P: Wound healing-aiming for perfect skin regeneration. Science 1997, 276:75-81

22. Galiano RD, Michaels J, Dobryansky M, Levine JP, Gurtner GC: Quantitative and reproducible murine model of excisional wound healing. Wound Repair Regen 2004, 12:485-492

23. Mustoe TA, Pierce GF, Thomason A, Gramates P, Sporn MB, Deuel TF: Accelerated healing of incisional wounds in rats induced by transforming growth factor-beta. Science 1987, 237:1333-1336

24. Quaglino D Jr, Nanney LB, Ditesheim JA, Davidson JM: Transforming growth factor-beta stimulates wound healing and modulates extracellular matrix gene expression in pig skin: incisional wound model. J Invest Dermatol 1991, 97:34-42

25. Roberts AB, Sporn MB, Assoian RK, Smith JM, Roche NS, Wakefield LM, Heine UI, Liotta LA, Falanga V, Kehrl JH: Transforming growth factor type beta: rapid induction of fibrosis and angiogenesis in vivo 
and stimulation of collagen formation in vitro. Proc Natl Acad Sci USA 1986, 83:4167-4171

26. Sporn MB, Roberts AB: A major advance in the use of growth factors to enhance wound healing. J Clin Invest 1993, 92:2565-2566

27. Wang X, Smith P, Pu LL, Kim YJ, Ko F, Robson MC: Exogenous transforming growth factor beta(2) modulates collagen I and collagen III synthesis in proliferative scar xenografts in nude rats. J Surg Res 1999, 87:194-200

28. Desmouliere A, Geinoz A, Gabbiani F, Gabbiani G: Transforming growth factor-beta 1 induces alpha-smooth muscle actin expression in granulation tissue myofibroblasts and in quiescent and growing cultured fibroblasts. J Cell Biol 1993, 122:103-111

29. Hales AM, Schulz MW, Chamberlain CG, McAvoy JW: TGF-beta 1 induces lens cells to accumulate alpha-smooth muscle actin, a marker for subcapsular cataracts. Curr Eye Res 1994, 13:885-890

30. Kurosaka D, Kato K, Nagamoto T, Negishi K: Growth factors influence contractility and alpha-smooth muscle actin expression in bovine lens epithelial cells. Invest Ophthalmol Vis Sci 1995, 36:1701-1708

31. Cucoranu I, Clempus R, Dikalova A, Phelan PJ, Ariyan S, Dikalov S, Sorescu D: NAD(P)H oxidase 4 mediates transforming growth factorbeta1-induced differentiation of cardiac fibroblasts into myofibroblasts. Circ Res 2005, 97:900-907

32. Narine K, DeWever O, Cathenis K, Mareel M, Van Belleghem Y, Van Nooten G: Transforming growth factor-beta-induced transition of fibroblasts: a model for myofibroblast procurement in tissue valve engineering. J Heart Valve Dis 2004, 13:281-289; discussion 289

33. Shephard P, Hinz B, Smola-Hess S, Meister JJ, Krieg T, Smola H: Dissecting the roles of endothelin: TGF-beta and GM-CSF on myofibroblast differentiation by keratinocytes. Thromb Haemost 2004, 92:262-274

34. Steffensen B, Hakkinen L, Larjava H: Proteolytic events of woundhealing-coordinated interactions among matrix metalloproteinases (MMPs), integrins, and extracellular matrix molecules. Crit Rev Oral Biol Med 2001, 12:373-398

35. Zimmermann F: Where are they going? Directed cell movement in morphogenesis. Genome Biol 2001, 2:REPORTS4014

36. Colwell AS, Longaker MT, Lorenz HP: Fetal wound healing. Front Biosci 2003, 8:S1240-S1248

37. Rowlatt U: Intrauterine wound healing in a 20-week human fetus. Virchows Arch A Pathol Anat Histol 1979, 381:353-361

38. Moulin V, Plamondon M: Differential expression of collagen integrin receptor on fetal vs. adult skin fibroblasts: implication in wound contraction during healing. Br J Dermatol 2002, 147:886-892

39. Denton CP, Khan K, Hoyles RK, Shiwen X, Leoni P, Chen Y, Eastwood M, Abraham DJ: Inducible lineage-specific deletion of TbetaRII in fibroblasts defines a pivotal regulatory role during adult skin wound healing. J Invest Dermatol 2009, 129:194-204
40. Mauviel A: Transforming growth factor-beta signaling in skin: stromal to epithelial cross-talk. J Invest Dermatol 2009, 129:7-9

41. Chesney J, Bucala R: Peripheral blood fibrocytes: novel fibroblastlike cells that present antigen and mediate tissue repair. Biochem Soc Trans 1997, 25:520-524

42. Krummel TM, Michna BA, Thomas BL, Sporn MB, Nelson JM, Salzberg AM, Cohen IK, Diegelmann RF: Transforming growth factor beta (TGFbeta) induces fibrosis in a fetal wound model. J Pediatr Surg 1988, 23:647-652

43. Chmielowiec J, Borowiak M, Morkel M, Stradal T, Munz B, Werner S, Wehland J, Birchmeier C, Birchmeier W: c-Met is essential for wound healing in the skin. J Cell Biol 2007, 177:151-162

44. Letterio JJ, Roberts AB: Regulation of immune responses by TGFbeta. Annu Rev Immunol 1998, 16:137-161

45. Wahl SM, Wen J, Moutsopoulos N: TGF-beta: a mobile purveyor of immune privilege. Immunol Rev 2006, 213:213-227

46. Kim SJ, Letterio J: Transforming growth factor-beta signaling in normal and malignant hematopoiesis. Leukemia 2003, 17:1731-1737

47. Darby IA, Hewitson TD: Fibroblast differentiation in wound healing and fibrosis. Int Rev Cytol 2007, 257:143-179

48. Gabbiani G, Badonnel MC: Contractile events during inflammation Agents Actions 1976, 6:277-280

49. Powell DW, Mifflin RC, Valentich JD, Crowe SE, Saada JI, West AB Myofibroblasts. I. Paracrine cells important in health and disease. Am J Physiol 1999, 277:C1-C9

50. Peacock EE, Jr: Future trends in wound healing research. Plast Surg Nurs 1984, 4:32-35

51. Reynolds LE, Conti FJ, Lucas M, Grose R, Robinson S, Stone M, Saunders G, Dickson C, Hynes RO, Lacy-Hulbert A, Hodivala-Dilke K: Accelerated re-epithelialization in beta3-integrin-deficient- mice is associated with enhanced TGF-beta1 signaling. Nat Med 2005, 11:167-174

52. Grenache DG, Zhang Z, Wells LE, Santoro SA, Davidson JM, Zutter MM: Wound healing in the alpha2beta1 integrin-deficient mouse: altered keratinocyte biology and dysregulated matrix metalloproteinase expression. J Invest Dermatol 2007, 127:455-466

53. Zweers MC, Davidson JM, Pozzi A, Hallinger R, Janz K, Quondamatteo $F$, Leutgeb B, Krieg T, Eckes B: Integrin alpha2beta1 is required for regulation of murine wound angiogenesis but is dispensable for reepithelialization. J Invest Dermatol 2007, 127:467-478

54. Parks WC: What is the alpha2beta1 integrin doing in the epidermis? J Invest Dermatol 2007, 127:264-266

55. Bear JE, Svitkina TM, Krause M, Schafer DA, Loureiro JJ, Strasser GA, Maly IV, Chaga OY, Cooper JA, Borisy GG, Gertler FB: Antagonism between Ena/VASP proteins and actin filament capping regulates fibroblast motility. Cell 2002, 109:509-521 